Dawid Szostek,

Ph.D., Associate Professor, Nicolaus Copernicus University in Torun, Poland

ORCID ID, 0000-0001-6743-854X

email: dawidsz@umk.pl

Correspondence author: dawidsz@umk.pl

\title{
INNOVATIONS IN HUMAN RESOURCE MANAGEMENT: IMPACT OF DEMOGRAPHIC CHARACTERISTICS, QUALITY OF INTERPERSONAL RELATIONSHIPS ON COUNTERPRODUCTIVE WORK BEHAVIOURS
}

\begin{abstract}
This paper describes the selected demographic characteristics as moderators of the impact of the quality of interpersonal relationships at work on counterproductive work behaviours. The main purposes of the research are describing: 1) how interpersonal relationships at work influences the intensity of counterproductive work behaviours; 2) how sex, age, education, length of service and type of job moderate the influence of interpersonal relationships at work on counterproductive work behaviours; 3) how the above-mentioned demographic characteristics influence interpersonal relationships at work and counterproductive work behaviours separately. The studies on the literature indicated that there were no comprehensive research results concerning those problems. The research paper fills a gap in the literature relating to the impact of interpersonal relationships at work on counterproductive work behaviours and the relation to modelling this impact by demographic characteristics of employees (sex, age, education, length of service, type of job). To achieve the study purposes, the author conducted a survey conducted on a sample of 1336 active employees in Poland. The survey period was 2018-2019. The IBM SPSS Statistics and IBM SPSS Amos were used to analyze data. Based on Structural Equation Modelling, it was that:1) interpersonal relationships at work negatively impacted on the intensity of counterproductive work behaviours against another individual; 2) the strength of influence of interpersonal relationships at work on counterproductive work behaviours did not change relevantly in modelling with selected demographic characteristics (sex, age, education, length of service, type of job); 3) only education, current kind of job and service length had a relevant influence on interpersonal relationships at work and counterproductive work behaviours. The research results could be useful for managers. In their activities, managers should systematically monitor interpersonal relationships at work and counterproductive work behaviours taking into account employees' demographic characteristics. In this process, managers should pay particular attention to education, type of current job, and service length.
\end{abstract}

Keywords: human resources, management, counterproductive behavior, workforce, interpersonal relationships.

Introduction. The quality of interpersonal relationships at work (QR) determines employees' behaviours both at work and in private life (Allen and Eby, 2012; Dutton, 2012). The high quality of the relationships has a positive influence on, e.g., commitment, performance, motivation, innovativeness, detectability of errors, OHS, cooperation in a team, helping others, communication within an organization and with the environment, absences, conflicts or resistance to negative events (Pisar and Bilkova, 2019). On the other hand, the low quality of these relationships has a negative influence on the aspects of an organization functioning (Carmeli and Gittell, 2009; Bono and Yoon, 2012; Halbesleben, 2012; PeyratGuillard and Glinska-Newes, 2014; Glinska-Newes, 2017; Polyanska et al., 2019; Jedrzejczak-Gas and Wyrwa, 2020; Draskovic et al., 2020). Considering the above, counterproductive work behaviours (CWB) must be influenced by the quality of interpersonal relationships at work. That is the case because these behaviours are conditioned by a group (George, 1990). The relation is quite clear. Therefore, if the relationships' quality is high, employees will be less likely to undertake CWB. Likewise, if QR is low, employees will be more likely to undertake CWB. Unfortunately, so far, understanding of these relations

Cite as: Szostek, D. (2021). Innovations in Human Resource Management: Impact of Demographic Characteristics, Quality of Interpersonal Relationships on Counterproductive Work Behaviours. Marketing and Management of Innovations, 1, 11-20. http://doi.org/10.21272/mmi.2021.1-01 
has been rather based on paradigms. In turn, available empirical research on the subject does not have a comprehensive character and focuses on selected aspects of the QR influence on CWB. For instance, Skarlicki and Folger (1997) examined QR influence upon retaliating activities of workers. Brass et al. (1998) analyzed the QR influence upon plotting, whereas Roberts (2009) focused on the significance of this quality for the staff's absence and conservative activities.

Research relating to moderation of the influence of CWB on QIRW by such important demographic variables as sex, age, education, length of service and type of job is even more fragmentary. These determinants are one of the most frequently considered in the personnel management literature (Tschan et al., 2004; Bowler and Brass, 2006; LePine et al., 2012; Chmelewska, 2012; Lu et al., 2020). Generally, available research relates to the type of job. For instance, according to Salminen et al. (2010), white-collar workers tend to undertake CWB more rarely than blue-collar workers. Considering the identified research gaps, the author formulated the following purposes:

1) describing how $Q R$ influences the intensity of CWB;

2) describing how sex, age, education, length of service and type of job moderate the influence of QR on CWB;

3) describing how the above-mentioned demographic characteristics influence $Q R$ and CWB separately.

Literature Review. Relationships at work have a dual character. It means that they could be positive (high quality) or negative (low quality). The first type is more intimate. It is based on trust and characterized by more frequent interactions and longer-lasting. The positive emotions express this relationship. On the other hand, negative relationships are short-term relationships based on suspicions, formality, and little emotions (or defined by negative emotions). A lot of factors make deliberations on the quality of interpersonal relationships at work difficult. Firstly, it is a type of continuum, i.e. the quality could be graded. What is more, in practice, it seems easier to qualify the relationships as high quality than low quality (Szostek and Glinska-Newes, 2017). Due to the presence of negative aspects (or absence of positive aspects), it should be considered that the whole relationship is negative. In turn, the presence of positive aspects (or absence of negative aspects) does not mean that the whole relationship is positive. The result indicated that there is no clear definition of $\mathrm{QR}$ (Table 1).

Table 1. Selected definitions and understanding of interpersonal relationships at work

\begin{tabular}{|c|c|}
\hline Source & Definition \\
\hline (Gabarro, 1990, p. 8) & $\begin{array}{l}\text { «Interpersonal relationship that is task-based, nontrivial, and of continuing } \\
\text { duration.» }\end{array}$ \\
\hline (Storbacka et al., 1994) & $\begin{array}{l}\text { entified with its strength of links between the parties that lead to satisfaction } \\
\text { mitment. }\end{array}$ \\
\hline (Hinde, 1997, p. 37) & $\begin{array}{l}\text { series of interactions between two people, involving interchanges over an } \\
\text { tended period». }\end{array}$ \\
\hline $\begin{array}{l}\text { (Sherony a } \\
\text { (McGinn a } \\
\text { p. 265) }\end{array}$ & $\begin{array}{l}\text { It is the level of mutual respect, trust and sense of duty between employees. } \\
\text { "Quality of relationship entails a pervasive, intentional, and constructive focus on } \\
\text { mutual support and members as individuals». }\end{array}$ \\
\hline (McCaule & $\begin{array}{l}\text { Sequence of interactions between two people that involves some degree of } \\
\text { utuality, in that the behaviour of one member takes some account of the behaviour } \\
\text { the other». }\end{array}$ \\
\hline & $\begin{array}{l}\text { valuation of the coworkers' actions, their feelings and attitudes, and the } \\
\text { nship's results. }\end{array}$ \\
\hline (Tep & how far a relationship is \\
\hline (Atrek et al., 2014) & $\begin{array}{l}\text { e degree to which a relationship meets the coworkers' expectations, needs and } \\
\text { pirations. }\end{array}$ \\
\hline
\end{tabular}

Sources: developed by the author. 
The category is outstandingly subjective, i.e. depends on one's individual perception of dominant aspects of a given relationship and assessment, whether expectations associated with a relationship have been fulfilled (Atrek et al., 2014). Thus, it is a multidimensional variable containing various aspects of exchange as part of interactions. Additionally, it is under the influence of numerous individual and contextual conditions. Szostek (2019) proposed four categories of the quality of interpersonal relationships at work as follows:

1) organizational atmosphere (e.g. atmosphere at work, trust, the way of mutual treatment, showing positive emotions);

2) interpersonal bonds (e.g. talking about private life, after-work meetings, helping behaviours, celebrating important occasions at work);

3) interpersonal relationships building methods (e.g. ensuring good conditions at work, regular meetings of the staff, employee opinion surveys, corporate events for employees);

4) distance resulting from management style (e.g. fair treatment by a supervisor, «human approach» towards subordinates, private contacts with the supervisor after work).

What is more, the author divided manifestations of $Q R$ into two dimensions, namely determinants vs results of the quality (some of the manifestations have a dual role, e.g. trust among coworkers) and organizational manifestations (activities undertaken by an organization) vs individual manifestations (activities undertaken by an employee). Counterproductive behaviour in organizations is the antithesis of constructive work attitudes represented, for example, by the school of Positive Organizational Behaviour (Przytula et al., 2014; Rozkwitalska et al., 2017, Lenart-Gansiniec and Sulkowski, 2020).

Counterproductive work behaviours are often understood as negative, wrong, pathological, deviant, dysfunctional or unethical. However, these terms are not synonymous and do not reflect the essence of the behaviour (Szostek, 2015). Aside from differences in terminology, the behaviours could be called counterproductive if the following three conditions meet together (Spector \& Fox, 2010; Nerdinger, 2011):

1) the organizational rules are hurt;

2) the behaviour was undertaken voluntarily;

3 ) it is detrimental (also potentially) to an organization and/or its stakeholders.

It is impossible to mention all possible manifestations of CWB. However, some authors proposed different typologies of CWB. The most often mentioned classification is the one proposed by Spector et al. (2006). The authors distinguished between two dimensions of the behaviours, namely CWB-I (addressing to other individuals, i.e. individual-oriented) and CWB-O (addressing to an organization, i.e. organizational-oriented). They also proposed five categories of these behaviours, such as:

1) abuse against others - behaviours detrimental to other people within an organization (e.g. lying, gossiping, harassment);

2) production deviance - an employee's fulfilment of his/her duties in a manner preventing from completion of work (concerning the quality and/or quantity of results);

3) sabotage - deliberate destroying of organizational property (including tangible and intangible assets, e.g. an organizational image);

4) theft - willful misappropriation of organizational or other personal property;

5) withdrawal - limitation of one's work below the minimum necessary to realize organizational goals.

Methodology and research methods. The survey was conducted in 2018 and 2019 based on triangulation of research methods, i.e. an online, direct and auditory questionnaire (approx. $80 \%$ of the data was collected using an online survey). It covered active employees in Poland, and the sample was non-random. Invitation for participation in the research was sent to:

- commune offices in Poland (nearly 2.5 thousand);

- 200 enterprises mentioned in the ranking list of Wprost weekly (200 largest enterprises in 2017);

- 26 enterprises from the Kujawsko-Pomorskie region, including 20 selected as based on a ranking list of 500 largest Polish enterprises as published in «Rzeczpospolita» journal for 2016; 
D., Szostek. Innovations in Human Resource Management: Impact of Demographic Characteristics, Quality of Interpersonal Relationships on Counterproductive Work Behaviours

- students of the Faculty of Economic Sciences and Management of Nicolaus Copernicus University in Torun (nearly 3.2 thousand);

- active workers who the author knows, including encouraged through Facebook (around 300 persons in total).

The research on CWB was made using the CWB-C scale (Counterproductive Work Behaviour Checklist) proposed by Spector et al. (2006). This scale is used for simultaneous measurement of numerous manifestations of such behaviours (there are 45 items in the most extensive version of the scale), dividing them into 5 categories (abuse against others, production deviance, thefts, sabotage, withdrawal) and 2 dimensions (individual- or organizational-oriented behaviours). A respondent assesses the frequency of own manifestations of CWB, indicating one of the following variants: never, once or twice, once or twice a month, once or twice a week, every day.

The quality of interpersonal relationships at work was measured using the QIRT-S scale (Quality of Interpersonal Relationships in the Team Scale) (Szostek, 2019). The scale includes 58 items. The respondent was asked to provide his/her opinion by indicating one of the following variants: strongly disagree; somewhat disagree; hard to say; somewhat agree; strongly agree. The statements could be divided into the 4 categories mentioned above of QR (organizational atmosphere, interpersonal bonds, interpersonal relationships building methods and distance resulting from management style) and 2 dimensions, i.e. determinants vs results of $Q R$ and organizational perspective vs individual perspective.

Following the collection and reduction of data (the author excluded 34 questionnaires, for which answers on the CWB-C scale were characterised by zero variance), the author obtained 1336 correctly completed questionnaires, which were analyzed using IBM SPSS Statistics and IBM SPSS Amos.

The collected data were characterized by high reliability concerning the quality of interpersonal relationships at work and counterproductive work behaviours. That is manifested by the Cronbach Alpha coefficient values (Lusnakova et al., 2019) (Table 2).

Table 2. Basic values for assessment of the reliability of the data collected

\begin{tabular}{ccccc}
\hline Scale & No. of positions & Cronbach Alpha & Average & Variance \\
\hline QIRT-S & 58 & 0.965 & 3.615 & 0.036 \\
CWB-C & 45 & 0.877 & 1.334 & 0.048 \\
\hline
\end{tabular}

Sources: developed by the author.

Table 3 provides the characteristic of respondents concerning selected demographic variables.

Table 3. Demographic characteristics of the sample

\begin{tabular}{|c|c|c|c|c|c|}
\hline \multirow{3}{*}{ Sex } & $F$ & $57.6 \%$ (770 persons) & & office/clerical & $49.9 \%$ (666 persons) \\
\hline & M & $40.6 \%$ (542 persons) & Type & management & $27.6 \%$ (369 persons) \\
\hline & No answer & 24 & & blue-collar & $20.5 \%$ (274 persons) \\
\hline \multirow{4}{*}{ Age } & AV & 40.3 years & & No answer & 27 persons \\
\hline & MIN & 18 years & $\operatorname{Re}$ & kujawsko-pomorskie & $19.4 \%$ (259 persons) \\
\hline & MAX & 67 years & gio & slaskie & $9.7 \%$ (129 persons) \\
\hline & $\mathrm{SD}$ & 11.8 years & $\mathrm{n}$ & malopolskie & $7.1 \%$ (95 persons) \\
\hline \multirow{6}{*}{ Education } & No answer & 70 persons & of & podlaskie & $6.0 \%$ (80 persons) \\
\hline & higher & $56.7 \%$ (757 persons) & Po & warminsko-mazurskie & $6.0 \%$ (80 persons) \\
\hline & secondary & $22.1 \%$ (295 persons) & lan & mazowieckie & $5.9 \%$ (79 persons) \\
\hline & vocational & $19.2 \%$ (256 persons) & $d$ & swietokrzyskie & $5.9 \%$ (79 persons) \\
\hline & basic & $0.3 \%$ (4 persons) & & pomorskie & $5.8 \%$ (77 persons) \\
\hline & No answer & 4 persons & & wielkopolskie & $5.3 \%$ (71 persons) \\
\hline
\end{tabular}


D., Szostek. Innovations in Human Resource Management: Impact of Demographic Characteristics, Quality of Interpersonal Relationships on Counterproductive Work Behaviours

\begin{tabular}{|c|c|c|c|c|}
\hline \multirow{5}{*}{$\begin{array}{l}\text { Length of } \\
\text { service }\end{array}$} & & & & \\
\hline & AV & 9.7 years & lubuskie & $4.8 \%$ (64 persons) \\
\hline & MIN & 1 month & lódzkie & 4.6\% (62 persons) \\
\hline & MAX & 48 years & podkarpackie & $4.5 \%$ (60 persons) \\
\hline & & 9.9 years & Lubelskie & $4.2 \%$ (56 persons) \\
\hline \multirow{3}{*}{$\begin{array}{c}\text { Sector of } \\
\text { employme } \\
\text { nt }\end{array}$} & No answer & 84 persons & dolnosląskie & $4.0 \%$ (53 persons) \\
\hline & private & $50.8 \%$ (679 persons) & opolskie & $3.4 \%$ (45 persons) \\
\hline & $\begin{array}{c}\text { public } \\
\text { No answer }\end{array}$ & $\begin{array}{c}48.9 \% \text { (653 persons) } \\
4 \text { persons }\end{array}$ & $\begin{array}{l}\text { zachodnio- } \\
\text { pomorskie }\end{array}$ & $3.1 \%$ (42 persons) \\
\hline
\end{tabular}

Sources: developed by the author.

Results. The starting point for further deliberations included structural modelling of the influence of the quality of interpersonal relationships at work on the intensity of counterproductive work behaviours (Derevianko, 2019). IBM SPSS Amos application limited the analysis in the case of CWB to the individual dimension of the behaviours (CWB-I) (Fig. 1 and Table 4).

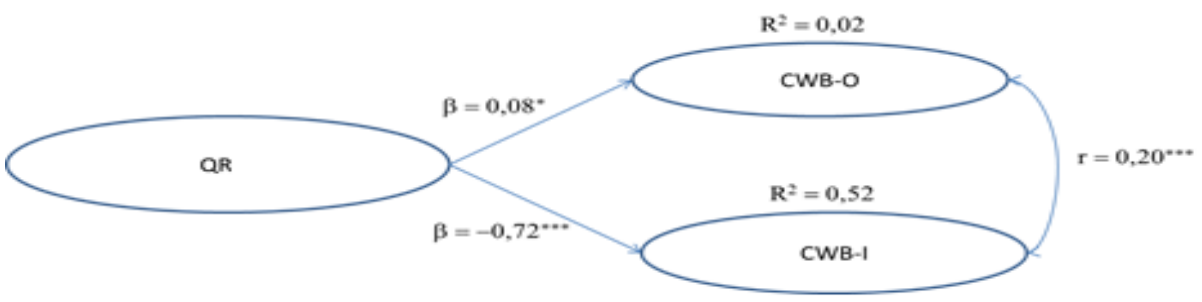

Meanings of symbols: * $-<0.05 ;{ }^{* * *}-<0.001$

Figure 1. SEM I structural model (influence of QR on CWB)

Sources: developed by the author.

Table 4. Parameters of SEM I structural model

\begin{tabular}{cccccc}
\hline Dependent variable & Predictor & B & S.E. & $\boldsymbol{\beta}$ & $\mathbf{p}$ \\
\hline CWB-O & \multirow{2}{*}{ QR } & 0.05 & 0.02 & 0.08 & $<0.05$ \\
CWB-I & & -0.66 & 0.05 & -0.72 & $<0.001$ \\
\hline
\end{tabular}

Sources: developed by the author.

The quality of interpersonal relationships at work significantly impacted the intensity of CWB towards other persons $\left(\beta=-0.72 ; p<0.001 ; R^{2}=0.52\right)$. With the growth of the relationships' quality by 1 standard deviation, counterproductive work behaviours were reduced by 0.72 of the standard deviation. What is more, CWBs-I were explained by QR in as much as $52 \%$. This trend and the strength of the influence of QR on CWB-I seem to be understandable. Both components are based upon an interpersonal factor. Thus, improvement (or worsening) of relationships between employees influences their likeliness to engage in various manifestations of negative behaviours towards other people.

On the other hand, concerning CWB-O, the influence of the quality of relationships on such behaviours' intensity seems to be contrary to logic $\left(\beta=0,08, p<0,05 ; R^{2}=0,02\right)$. The relationship's growth by 1 standard deviation caused growing organization-oriented counterproductive work behaviours by 0.08 of the standard deviation. The relation was weak and explained only $2 \%$ of variances of CWB-O. The relation explains that the higher quality of the relationship between employees, the more likely are the employees to engage in such counterproductive work behaviours in a situation when the welfare of any of the employees is infringed (e.g. CWB-O may, in this case, constitute a form of retaliation against an organization). In this paper, the criteria CMIN/DF was used to check the model acceptance. Notably, CMIN 
means model matching test statistics. In turn, DF is the number of various elements of the variancecovariance matrix decreased by the estimated parameters. Researchers recommend that the models in which CMIN/DF exceeds 2 should be rejected. However, other authors accept less restrictive limits (5 and even 10) (Bedyńska and Książek, 2012) Therefore, SEM I matches the data within an acceptable framework. CMIN/DF statistics are close to the limit of acceptance $(<5)$. RMSEA means divergences between the theoretical and population variance-covariance matrix as adjusted by the number of degrees of freedom. There are the following generally acceptable thresholds for the statistics:

- $<0.05$ good matching of the model and the data,

- 0.05-0.08 satisfactory matching,

- 0.08-0.10 poor matching,

- 0.1 unacceptable matching (Bedyńska and Ksiażek, 2012).

However, the limits are not exceeded. On the other hand, the RMSEA statistics' value proves a perfect model matching $(<0.05)$. The remaining statistics prove moderate matching of the model (Table 5).

Table 5. Statistics of matching of SEM I model with the data

\begin{tabular}{ccccc}
\hline NPAR & CMIN & DF & P & CMIN/DF \\
\hline 294 & 19098,29 & 4556 & $<0.001$ & 4.192 \\
RMSEA & NFI & TLI & CFI & IFI \\
0.05 & 0.68 & 0.73 & 0.74 & 0.74 \\
\hline
\end{tabular}

Sources: developed by the author.

Another step involved modelling the influence of the quality of the interpersonal relationships at work on the intensity of counterproductive work behaviours in consideration of 5 demographic variables (sex, age, education, length of service, type of job). The strength of influence QR on CWB did not change significantly in this case as compared to the model without the controlling variables (Fig. 1 and Fig. 2). It means that the variables explained a unique part of the variances of counterproductive work behaviours.

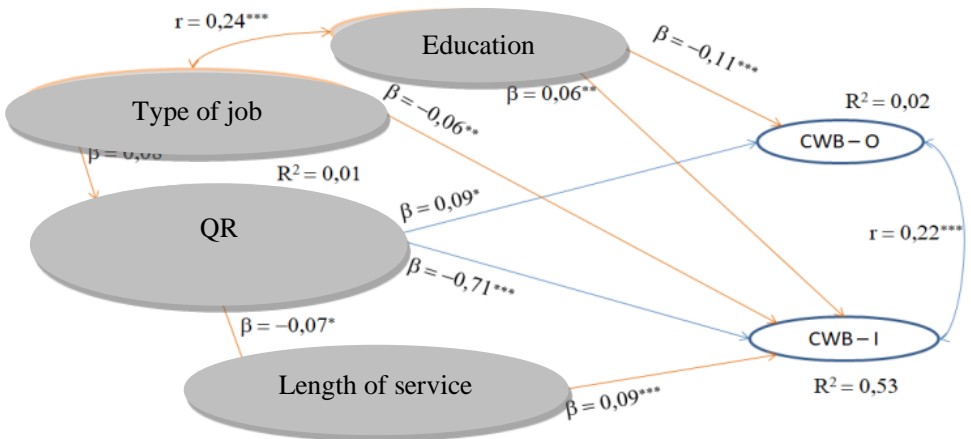

Figure 2. SEM II structural model (influence of QR on CWB in consideration of demographic variables)

Meaning of symbols: ${ }^{*}-<0.05 ;{ }^{* *}-<0.01 ;{ }^{* * *}-<0.001$

Source: developed by the author.

The author also analyzed the influence of demographic variables on each of the constructs individually (e.g. on QR and CWB). Most of all, the author noticed the absence of significant influence of sex and age upon the constructs. Therefore, they were eliminated from further deliberations (Table 6). 
D., Szostek. Innovations in Human Resource Management: Impact of Demographic Characteristics, Quality of Interpersonal Relationships on Counterproductive Work Behaviours

Table 6. The influence of a respondent's sex and age on $Q R$ and CWB

\begin{tabular}{cccccc}
\hline Dependent variable & Predictor & B & S.E. & $\boldsymbol{\beta}$ & $\mathbf{p}$ \\
\hline QR & Sex & 0.04 & 0.03 & 0.04 & 0.15 \\
CWB -0 & Sex & 0.03 & 0.01 & 0.06 & 0.06 \\
CWB - & Sex & 0.03 & 0.02 & 0.03 & 0.13 \\
CWB -0 & Age & 0.00 & 0.00 & 0.02 & 0.58 \\
CWB-I & Age & 0.00 & 0.00 & 0.03 & 0.18 \\
QR & Age & 0.00 & 0.00 & $-0,01$ & 0.76 \\
\hline
\end{tabular}

Sources: developed by the author.

The analysis showed that the higher the level of education of an employee, the lower intensity of CWB$O$ and the higher intensity of CWB-I. Apart from that, education did not influence QR. The author observed that the higher type of position was held by a respondent, the higher quality of the interpersonal relationships at work and the lower intensity of CWB-I. The author did not record any influence of this demographic variable upon CWB-O. On the other hand, the length of service affected both analyzed constructs, i.e. the longer the respondents' service, the lower $Q R$ and the higher intensity of CWB-I. Besides, in the case of this variable, the author did not record any influence on CWB-O. Figure 2 Table 7 present the relationships mentioned above.

Table 7. SEM II structural model parameters

\begin{tabular}{cccccc}
\hline Dependent variable & Predictor & B & S.E. & $\boldsymbol{\beta}$ & $\mathbf{p}$ \\
\hline QR & The length of service & 0.00 & 0.00 & -0.07 & $<0.05$ \\
QR & Type of current job & 0.06 & 0.02 & 0.08 & $<0.01$ \\
CWB-O & QR & 0.05 & 0.02 & 0.09 & $<0.05$ \\
CWB-I & QR & -0.65 & 0.05 & -0.71 & $<0.001$ \\
CWB-O & Education & -0.04 & 0.01 & -0.11 & $<0.001$ \\
CWB-I & Education & 0.04 & 0.01 & 0.06 & $<0.01$ \\
CWB-I & The length of service & 0.00 & 0.00 & 0.09 & $<0.001$ \\
CWB-I & Type of job & -0.04 & 0.01 & -0.05 & $<0.01$ \\
\hline
\end{tabular}

Sources: developed by the author.

Model SEM II matched the data within an acceptable framework. CMIN/DF statistics were close to the limit of acceptance $(<5)$. However, the limits were not exceeded. The value of RMSEA statistic proves good matching of the model $(<0,05)$. The remaining statistics prove moderately good matching of the model (Table 8).

Table 8. Statistics of matching of SEM II model with the data

\begin{tabular}{ccccc}
\hline NPAR & CMIN & DF & $\mathbf{P}$ & CMIN/DF \\
\hline 307.00 & 19862.52 & 4843.00 & $<0.001$ & 4.10 \\
RMSEA & NFI & TLI & CFI & IFI \\
0.05 & 0.68 & 0.72 & 0.73 & 0.73 \\
\hline
\end{tabular}

Sources: developed by the author.

Conclusions. To conclude the deliberations presented in this paper, it stands to note that all the purposes were achieved (Skarlicki and Folger, 1997; Brass et al., 1998; Roberts, 2009) and, thus:

1) it was described how $Q R$ influenced the intensity of the counterproductive relationship at work (SEM I model). Structural modelling proved the existence of the influence and its strength and relevance, however, only concerning counterproductive work behaviours against other individuals (CWB-I); 
2) it was described how selected demographic variables (sex, age, education, length of service, type of job) moderated the influence of $Q R$ on CWB (see SEM II model). It turned out that the strength of influence of QR on CWB did not change significantly compared to a model that did not include the abovementioned demographic variables;

3) it was described how the above-mentioned demographic characteristics influence $Q R$ and CWB-I and CWB-O. Variables that had a significant influence on the constructs included education, type of job, and service length.

The presented research results are non-representative, which results from the non-random selection of the sample. As a matter of fact, a relatively high quantity of respondents was a mitigating factor and the fact that employees were differentiated by sex, age, education, type of job and sector of employment, length of service and geographical location (region of Poland). However, further research should ensure random selection of the sample. Another problem included using methods of direct survey (a direct and auditory survey) in the data collection. That was confirmed by many questionnaires, where answers on the CWB-C scale were characterized by zero variance. Unwillingness to admit engagement on counterproductive work behaviours could result from a fear of losing anonymity by a respondent. Therefore, it was right to use the triangulation of research methods, including an online survey. Due to the research field's sensitive character, any further research should use indirect questionnaire methods and ensure the highest anonymity possible for respondents. That would allow increasing the reliability of obtained empirical material. Notwithstanding the above, the presented results have an explorative character to a great extent, which may justify the limitations mentioned above. The author believes that the limitations do not diminish this paper's value, including the deliberations' practical character for an organization's functioning. Most of all, the influence of QR on CWB was confirmed empirically. The author also indicated the strength and trend of the relevant demographic variables influence both constructs (e.g. $\mathrm{QR}$ and $\mathrm{CWB}$ ). All this should certainly be considered in the ongoing management of an organization, staff, and relationships between employees. The management should be conducted in such a manner as not only to eliminate manifestations of CWB but also to prevent such behaviours. That is a big responsibility of managers, which requires many soft competencies (Safrankova and Sikyr, 2018).

\section{References}

Allen, T. D., \& Eby, L. T. (2012). The study of interpersonal relationships: An introduction. Personal Relationships. The Effect on Employee Attitudes, Behavior, and Well-being, 3-14. [Google Scholar]

Atrek, B., Marcone, M. R., Gregori, G. L., Temperini, V., \& Moscatelli, L. (2014). Relationship quality in supply chain management: A dyad perspective. Ege Akademik Bakış Dergisi, 14(3), 371-382. [Google Scholar]

Bedynska, S., \& Książek, M. (2012). Statystyczny drogowskaz: praktyczny przewodnik wykorzystania modeli regresji oraz równan strukturalnych. Wydawnictwo Akademickie Sedno.

Bono, J. E., \& Yoon, D. J. (2012). Positive supervisory relationships. Personal relationships: The effect on employee attitudes, behavior and well-being, 43-66. [Google Scholar]

Bowler, W. M., \& Brass, D. J. (2006). Relational correlates of interpersonal citizenship behavior: a social network perspective. Journal of applied Psychology, 91(1), 70. [Google Scholar] [CrossRef]

Brass, D. J., Butterfield, K. D., \& Skaggs, B. C. (1998). Relationships and unethical behavior: A social network perspective. Academy of management review, 23(1), 14-31. [Google Scholar] [CrossRef]

Carmeli, A., \& Gittell, J. H. (2009). High-quality relationships, psychological safety, and learning from failures in work organizations. Journal of Organizational Behavior: The International Journal of Industrial, Occupational and Organizational Psychology and Behavior, 30(6), 709-729. [Google Scholar] [CrossRef]

Chmielewska, M. (2012). Marital quality in the context of interpersonal dependency. Economics \& Sociology, 5(2), 58. [Google Scholar

Counterproductive Work Behavior Checklist (CWB-C). (n.d.) Retrieved from [Link]

Derevianko, O. (2019). Reputation stability vs anti-crisis sustainability: under what circumstances will innovations, media activities and CSR be in higher demand?. Oeconomia Copernicana, 10(3), 511-536. [Google Scholar] [CrossRef] 


\section{D., Szostek. Innovations in Human Resource Management: Impact of Demographic Characteristics, Quality of}

Interpersonal Relationships on Counterproductive Work Behaviours

Draskovic, V., Jovovic, R., Streimikiene, D., \& Bilan, S. (2020). Formal and Informal vs. Alternative Institutions. Montenegrin Journal of Economics, 16(2), 193-201. [Google Scholar] [CrossRef]

Dutton, J. E. (2012). «Build High Quality Connections», in: Spreitzer, G., Dutton, J. E. (Eds.)ю How to Be a Positive Leader: Small Actions, Big Impacts, Berrett-Koehler Publishers, San Francisco. [Google Scholar]

Fox, S., Spector, P. E., \& Miles, D. (2001). Counterproductive work behavior (CWB) in response to job stressors and organizational justice: Some mediator and moderator tests for autonomy and emotions. Journal of vocational behavior, 59(3), 291 309. [Google Scholar] [CrossRef]

Gabarro, J. J. (1990). The development of working relationships. Intellectual teamwork: Social and technological foundations of cooperative work, 79, 110. [Google Scholar]

George, J. M. (1990). Personality, affect, and behavior in groups. Journal of applied psychology, 75(2), 107. [Google Scholar] [CrossRef]

Girchenko, T., Panchenko, O. (2020). Research on the practical aspects of the providing efficiency of marketing communications' bank. Financial and credit activity-problems of theory and practice, 3. P. 13-22. [Google Scholar] [CrossRef]

Glinska-Newes, A. (2017). Pozytywne relacje interpersonalne w zarządzaniu. Wydawnictwo Naukowe Uniwersytetu Mikolaja Kopernika. [Google Scholar]

Halbesleben, J. R. (2012). Positive coworker exchanges. Personal relationships. The effect on employee attitudes, behavior, and well-being, 107-130. [Google Scholar]

Hinde, R. A. (1997), Relationships: A Dialectical Perspective, Psychology Press, East Sussex, UK. [Google Scholar]

Jedrzejczak-Gas, J., \& Wyrwa, J. (2020). Determinants of job satisfaction in a transport company: a Polish case study. Equilibrium. Quarterly Journal of Economics and Economic Policy, 15(3), 565-593. [Google Scholar] [CrossRef]

Kuznyetsova A. Ya., Zherebylo I. V., Klipkova O. I., Kozmuk N. I. (2019). Creation of the value of national enterprises with the help of the innovation centers in the cluster formations. Financial and credit activities: problems of theory and practice, 2, 29. P. 391402. [CrossRef]

Kuznetsova A., Kalynets K., Kozmuk N. (2018). Innovative management in global financial csr governance. Marketing and management of innovations, 2, P. 262-269. [CrossRef]

Lenart-Gansiniec, R., \& Sulkowski, L. (2020). Organizational learning and value creation in local governance: the mediating role of crowdsourcing. Learning Organization, 27(4). [Google Scholar] [CrossRef]

LePine, J. A., Methot, J. R., Crawford, E. R., \& Buckman, B. R. (2012). A model of positive relationships in teams: The role of instrumental, friendship, and multiplex social network ties. Personal Relationships. The Effect on Employee Attitudes, Behavior, and Well-being, Routledge, New York, 173-194. [Google Scholar]

Lu, J., Ren, L., Zhang, C., Wang, C., Petkeviciute, N., \& Streimikis, J. (2020). Gender difference in corporate social respon sibility implementation in Lithuanian SMEs. Oeconomia Copernicana, 11(3), 549-569. [Google Scholar] [CrossRef]

Lusnakova, Z., Juríčkova, Z., Sajbidorova, M., \& Lenčésova, S. (2019). Succession as a sustainability factor of family business in Slovakia. Equilibrium. Quarterly Journal of Economics and Economic Policy, 14(3), 503-520. [Google Scholar] [CrossRef]

McCauley, C. D. (2012). Reflection on Integration: Supervisor-Employee Relationships. Personal Relationships. The Effect on Employee Attitudes, Behavior, and Well-being, 95-105. [Google Scholar]

McGinn, K. L. (2009), «History, Structure, and Practices: San Pedro Longshoremen in the Face of Change», in: Dutton, J.E., Ragins, B.R. (Eds.)ю Exploring Positive Relationships at Work. Building a Theoretical and Research Foundation, Psychology Press, East Sussex, UK; New York, USA. [Google Scholar]

Nerdinger, F. W. (2011). Formen des Arbeitsverhaltens. In Arbeits-und Organisationspsychologie (pp. 409-423). Springer, Berlin, Heidelberg. [Google Scholar] [CrossRef]

Peyrat-Guillard, D., \& Glinska-Newes, A. (2014). I Respect You and I Help You: Links Between Positive Relationships at Work and Organizational Citizenship Behaviour. Journal of Positive Management, 5(2), 82-96. [Google Scholar] [CrossRef]

Pisar, P., \& Bilkova, D. (2019). Controlling as a tool for SME management with an emphasis on innovations in the context of Industry 4.0. Equilibrium. Quarterly Journal of Economics and Economic Policy, 14(4), 763-785. [Google Scholar] [CrossRef] Polyanska, A., Zapukhliak, I., \& Diuk, O. (2019). Culture of organization in conditions of changes as an ability of efficient transformations: the case of gas transportation companies in Ukraine. Oeconomia Copernicana, 10(3), 561-580. [Google Scholar] [CrossRef

Przytula, S., Rozkwitalska, M., Chmielecki, M., Sulkowski, L., \& Basinska, B. A. (2014). Cross-cultural interactions between expatriates and local managers in the light of Positive Organizational Behaviour. Social Sciences, 86(4), 14-24. [Google Scholar] [CrossRef]

Roberts, L. M. (2009). From Proving to Becoming: How Positive Relationships Create a Context for Self-Discovery and SelfActualization, in: Dutton, J. E., Ragins, B. R. (Eds.), Exploring Positive Relationships at Work. Building a Theoretical and Research Foundation, Psychology Press, East Sussex/New York. [Google Scholar]

Rozkwitalska, M., Chmielecki, M., Przytula, S., Sulkowski, L., \& Basinska, B. (2017). Intercultural interactions in multinational subsidiaries. Baltic Journal of Management, 12(2), 214-239. [Google Scholar] [CrossRef]

Rzeczpospolita. (2016). The List of 500 - Edition 2016. Retrieved from [Link]

Safrankova, J. M., \& Sikyr, M. (2018). Responsibilities and competencies in personnel management at Czech schools. Oeconomia Copernicana, 9(3), 529-543. [Google Scholar] [CrossRef] 
D., Szostek. Innovations in Human Resource Management: Impact of Demographic Characteristics, Quality of Interpersonal Relationships on Counterproductive Work Behaviours

Salminen, A., \& Ikola-Norrbacka, R. (2010). Trust, good governance and unethical actions in Finnish public administration. International Journal of Public Sector Management, 23(7), 647-668. [Google Scholar] [CrossRef]

Sherony, K. M., \& Green, S. G. (2002). Coworker exchange: relationships between coworkers, leader-member exchange, and work attitudes. Journal of applied psychology, 87(3), 542. [Google Scholar] [CrossRef]

Skarlicki, D. P., \& Folger, R. (1997). Retaliation in the workplace: The roles of distributive, procedural, and interactional justice. Journal of applied Psychology, 82(3), 434. [Google Scholar] [CrossRef]

Spector, P. E., \& Fox, S. (2010). Counterproductive work behavior and organizational citizenship behavior: Are they opposite forms of active behavior?. Applied Psychology, 59(1), 21-39. [Google Scholar] [CrossRef]

Spector, P. E., Fox, S., Penney, L. M., Bruursema, K., Goh, A., \& Kessler, S. (2006). The dimensionality of counterproductivity: Are all counterproductive behaviors created equal?. Journal of vocational behavior, 68(3), 446-460. [Google Scholar] [CrossRef]

Storbacka, K., Strandvik, T., \& Grönroos, C. (1994). Managing customer relationships for profit: the dynamics of relationship quality. International journal of service industry management, 5(5), pp. 21-38. [Google Scholar] [CrossRef]

Szostek, D. (2015). Dysfunkcjonalne zachowania pracowników: zarys problematyki. Zarządzanie Zasobami Ludzkimi, 1, 69-82. [Google Scholar]

Szostek, D. (2019). Kontrproduktywne zachowania organizacyine w kontekscie jakosci relacji interpersonalnych w zespolach pracowniczych. Wydawnictwo Naukowe Uniwersytetu Mikolaja Kopernika. [Google Scholar]

Szostek, D., \& Glinska-Newes, A. (2017). Identyfikacja wymiarów jakosci relacji interpersonalnych w organizacji. Organizacja i Kierowanie, 3(177), 11-24. [Google Scholar]

Tepper, B. J., \& Almeda, M. (2012). Negative Exchanges With Supervisors. Personal Relationships: The Effect on Employee Attitudes, Behavior, and Well-being, 67. [Google Scholar]

Tschan, F., Semmer, N. K., \& Inversin, L. (2004). Work related and "private"social interactions at work. Social Indicators Research, 67(1), 145-182. [Google Scholar] [CrossRef]

Wprost. (2017). Ranking of 200 Largest Polish Companies in 2017. Retrieved from [Link]

Давид Шостек, Ph.D., доцент, Університет Миколи Коперника в Торуні, Польща

Інновації в управлінні людськими ресурсами: вплив демографічних факторів та міжособистісних відносин у колективі на контрпродуктивність працівників

У статті узагальнено науковий доробок щодо інноваційних методів підвищення продуктивності праці в організації. Автором визначено, що основними факторами $є$ демографічні та якість міжособистісних відносин працівників. У статті проаналізовано специфіку впливу якості міжособистісних відносин у трудовому колективі на контрпродуктивність працівників (як оберненого показника продуктивності праці). Оцінено силу впливу демографічного фактору на якість міжособистісних відносини у трудовому колективі та контрпродуктивність працівників. У якості параметрів, що описують демографічн фактори обрано: стать, вік, освіта, стаж та тип роботи. Вихідні данні для дослідження сформовано на основі опитування 1336 респондентів, які працюють у Польщі. Період дослідження - 2018-2019 роки. Для аналізу даних застосовано програмне забезпечення IBM SPSS Statistics та IBM SPSS Amos. Методологію дослідження засновано на використанні інструментарію структурного моделювання. За результатами емпіричних розрахунків встановлено, що: 1) якість міжособистісних відносин у трудовому колективі має статистично значущий негативний вплив на контрпродуктивність його працівників; 2) сила впливу якості міжособистісних відносин у трудовому колективі на контрпродуктивність його працівників не залежить від демограффічних факторів (статі, віку, освіти, стажу та типу роботи); 3) освіта, тип та стаж роботи мають статистично значущий вплив як на якість міжособистісні відносини у трудовому колективі, так і на контрпродуктивність його працівників. Результати дослідження мають практичне значення та можуть бути корисними для менеджерів організацій. Автором наголошено, що менеджерам організацій необхідно систематично контролювати якість міжособистісних відносин у трудовому колективі та контрпродуктивність його працівників з урахуванням демографічних факторів, де особливу увагу слід звертати на освіту, стаж та тип виконуваної роботи.

Ключові слова: людські ресурси, управління, контрпродуктивна поведінка, працівники, трудовий колектив, міжособистісні взаємовідносини. 